\title{
Effect of cadmium on the liver and amelioration by aqueous extracts of fenugreek seeds, rosemary, and cinnamon in guinea pigs: Histological and biochemical study
}

\author{
Mohamed Omer Albasha, Azab El-Saied Azab \\ Department of Zoology, Alejelat Faculty of Science, Zawia University, Libya \\ Email address: \\ azabelsaied@yahoo.com (A. E. Azab)
}

\section{To cite this article:}

Mohamed Omer Albasha, Azab El-Saied Azab. Effect of Cadmium on the Liver and Amelioration by Aqueous Extracts of Fenugreek Seeds, Rosemary, and Cinnamon in Guinea pigs: Histological and Biochemical Study. Cell Biology. Vol. 2, No. 2, 2014, pp. 7-17. doi: $10.11648 /$ j.cb. 20140202.11

\begin{abstract}
Hepatotoxic agents can react with the basic cellular components and consequently induce almost all types of liver lesions. Objective: The present work aimed to evaluate effectiveness of fenugreek seeds, rosemary and cinnamon against cadmium induced hepatotoxicity in guinea pigs from the histological and biochemical aspects. Materials and methods: 48 guinea pigs were used for this study and divided into 8 groups. The first 4 groups were control groups, the $5^{\text {th }}$ group was the experimental and administered oral cadmium chloride at a dose of $5 \mathrm{mg} / \mathrm{kg}$. body weight./day for 28 days, the $6^{\text {th }}, 7^{\text {th }}$, and $8^{\text {th }}$ groups co-administered cadmium with aqueous extracts of fenugreek seeds, rosemary and cinnamon at a dose of $150 \mathrm{mg}$, $220 \mathrm{mg}$, and $200 \mathrm{mg} / \mathrm{kg}$ body weight /day, respectively. The livers were dissected out, weighted and specimens were taken and processed for light microscopic examinations. Blood samples were obtained for assessment of serum alanine aminotransferase, aspartate aminotransferase, alkaline phosphatase, $\gamma$-glutamyltransferase activities, and serum total and direct bilirubin. Results: In cadmium treated animals, there were severe structural damage in the liver. Most of hepatocytes appeared fused together forming eosinophilic syncytial masses. The hepatocytes appeared irregularly arranged with disorganization of hepatic architecture. The hepatocytes appeared large with light and foamy cytoplasm filled with numerous vacuole-like spaces. The nuclei appeared with pyknotic nuclei. The central vein appeared dilated and congested with massive hemorrhage extending to the nearby cells. Mild periductal fibrosis around bile duct in the portal area were observed. Also, there were focal degenerative and necrotic changes along with inflammatory cell infiltration. Decrease in body weight and increase in liver weight were observed. Biochemically, the serum alanine aminotransferase, aspartate aminotransferase, alkaline phosphatase), and $\gamma$-glutamyltransferase activities, serum total and direct bilirubin were elevated. Co-adminstration of fenugreek, rosemary and cinnamon significantly improved the structural changes in the liver and also all the above mentioned biochemical parameters were significantly declined. Conclusion: It can be concluded that, the cadmium had adverse effects on the liver. Aqueous extracts of different natural materials as Fenugreek, rosemary and cinnamon were able to attenuate these effects. So, the populations of high risk to cadmium should be advised to take one of these materials.
\end{abstract}

Keywords: Cadmium, Hepatotoxicity, Serum Enzymes Activities (ALT, AST, ALP, $\gamma$-GT), Serum Bilirubin, Histology, Fenugreek Seeds, Rosemary, Cinnamon

\section{Introduction}

Hepatotoxic agents can react with the basic cellular components and consequently induce almost all types of liver lesions. Toxins and drugs are among the basic etiopathogenetic agents of acute liver failure in Western countries [1]. Cadmium $(\mathrm{Cd})$ is a relatively rare element that occurs naturally in rocks together with other heavy metals or emitted into the air through the process of volcanic emissions. It became commercial in the $20^{\text {th }}$ century due to agricultural and industrial applications [2]. Most of the available epidemiological information obtained from occupationally exposed populations in highly contaminated areas has established that excessive $\mathrm{Cd}$ exposure produces adverse health effects [3]. Cadmium may induce oxidative damage in different tissues by enhancing peroxidation of 
membrane lipids in tissues and altering the antioxidant systems of the cells [4]. Several experimental studies in various laboratories are underway, to study the prophylactic effect of various natural antioxidant compounds against toxic metals. Herbs are generally considered safe and proved to be effective against various human ailments and their medicinal uses have been gradually increasing in developed countries [5]. Natural antioxidants strengthen the endogenous antioxidants defenses from reactive oxygen species and restore the optimal balance by neutralizing the reactive species [6]. Fenugreek (Trigonella foenumgraecum $\mathrm{L}$ ) is an annual herb belonging to Legume family; it is widely grown in India, Egypt, and Middle Eastern countries [7]. It used both in medicine and with food as spice show antioxidant effect through their used in diabetes mellitus due to the presence of different active constituents such as flavonoids, alkaloids, vitamins and amino acids [8].

Rosemary (Rosmarinus officinalis) is a herb commonly used as spice and flavoring agents in food processing. Dried leaves and flowers constitutes a particularly interesting source of biologically active phytochemicals as it contains a variety of phenolic compounds including carnosol, carnosic acid, rosmanol, 7-methyl-epirosemanol, isorosmanol, rosmadial, and caffeic acid [6,9].

Cinnamon (Cinnamomum zeylanicum), the evergreen tree of tropical area, a member of family Lauraceae, has been used in day to day routine as a spice and condiment in India. Cinnamon is used to flavor most foods in Arabian countries [10].The bark of cinnamon is widely used as a spice due to its distinct odour of essential oils, and has been widely employed in the treatment and prevention of disease. Main chemical constituents are cinnamic acid, cinnamaldehyde, euginol, and essential oils. In medicine it acts like other volatile oils and once had a reputation as a cure for colds [11]. Most of the previous literatures studied the protective effects of one antioxidants substances on the biochemical hepatotoxicity of cadmium chloride but little of them which studied the morphological alterations. Also, to our knowledge, the evidence reporting the ameliorative effect of fenugreek seeds, rosemary and cinnamon against cadmium toxicity in liver are hardly found. So, the present work aimed to evaluate effectiveness of different natural materials (fenugreek seeds, rosemary and cinnamon) against the histological and also biochemical alterations of cadmium induced hepatotoxicity in guinea pigs.

\section{Materials and Methods}

\subsection{Chemicals}

Cadmium chloride was purchased from Sigma Chemical Co. (St. Louis, Mo, USA). Fenugreek seeds, rosemary and cinnamon powder were purchased from a herbal store in Sabrata, Libya.

Aqueous fenugreek seeds extract was prepared according to the method of Kassim [12]. Fifty grams of dried seeds of fenugreek has been crushed and slowly boiled in one liter of distilled water and heated for 30 minutes. The extracts were then filtered and directly administered orally by gavage to the animals. Aqueous rosemary extract was prepared according to the method of Amin and Hamza [13]. Briefly, ten grams of dried plants was slowly boiled in $100 \mathrm{ml}$ of distilled water and heated for 30 minutes. The extracts were then filtered and directly administered orally by gavage to the animals. The used dose was $220 \mathrm{mg} / \mathrm{kg}$ body wt. Crude. Aqueous cinnamon extract was prepared according to the method of Hasanein et al. [14]. Adding five grams of cinnamon to $100 \mathrm{ml}$. Water and boiled together for $2 \mathrm{~min}$. Infusion was cooled to room temperature and then filtered.

Cadmium chloride was given orally by gavage at the dose of $5 \mathrm{mg} / \mathrm{kg}$ body wt/day [15] in saline for 28 successive days. The choice of the doses of fenugreek seeds, rosemary and cinnamon were based on the results of the previous studies, where the antioxidant effect of these agents were confirmed. Aqueous fenugreek seeds extract was given orally at a dose of $150 \mathrm{mg} / \mathrm{kg}$ body wt by gavage [12]. Rosemary was given at a dose of $220 \mathrm{mg} / \mathrm{kg}$ body wt orally by gavage $[16,17]$, and the cinnamon was given at a dose of $4 \mathrm{ml} / \mathrm{each}$ animal/day (200mg/each animal/day) orally by gavage [14].

\subsection{Animals}

48 adult male guinea pigs weighting 450-510 gm were used for this study. The animals were obtained from animal house unit in the Faculty of Veterinary Medicine, Tripoli University, Libya. The animals were housed in a room under standard conditions of ventilation, temperature $\left(25 \pm 2^{\circ} \mathrm{C}\right)$, humidity $(60-70 \%)$ and light/dark condition (12/12). The animals were provided with tape water ad libitum and fed with the standard commercial chow. The animal procedures were performed in accordance with Guide Lines for Ethical Conduct in the Care and Use of Animals.

\subsection{Experimental Design}

After one week of acclimation, the animals were randomized and divided into 8 groups (6 guinea pigs for each) as follow:-

Group 1 (control group): The animals received normal saline for 28 days.

Group 2 (fenugreek only): The animals received fenugreek ( $150 \mathrm{mg} / \mathrm{kg}$ body wt/day) orally by gavage for 28 days.

Group 3 (rosemary only): The animals received rosemary $(220 \mathrm{mg} / \mathrm{kg}$ body wt /day) orally by gavage for 28 days.

Group 4 (cinnamon only): The animals received cinnamon (200mg/each animal/day) orally by gavage for 28 days.

Group 5 (cadmium chloride treated group): The animals received $\mathrm{CdCl} 2(5 \mathrm{mg} / \mathrm{kg}$ body wt/day) orally by gavage for 28 days.

Group 6 (cadmium chloride/fenugreek co-administered): The animals received $\mathrm{CdCl} 2(5 \mathrm{mg} / \mathrm{kg}$ body wt/day) orally by gavage concurrently with fenugreek $(150 \mathrm{mg} / \mathrm{kg}$ body wt /day ) orally for 28 days.

Group 7 (cadmium chloride /rosemary co-administered): The animals received $\mathrm{CdCl} 2(5 \mathrm{mg} / \mathrm{kg}$ body wt/day) orally 
by gavage concurrently with rosemary $(220 \mathrm{mg} / \mathrm{kg}$ body wt /day )orally for 28 days.

Group 8 (cadmium chloride/cinnamon co-administered): The animals received $\mathrm{CdCl} 2(5 \mathrm{mg} / \mathrm{kg}$ body wt/day) orally by gavage concurrently with cinnamon $(200 \mathrm{mg} / \mathrm{each}$ animal/day) orally for 28 days.

At the end of the experimentation and 24 hours after the last dose, all animals were weighted and then sacrificed under pentobarbital anaesthesia $(37 \mathrm{mg} / \mathrm{kg}$ ip) [18], then rapidly dissected and subjected to the following examinations:

\subsection{Histological Examination}

The liver was exposed by mid line incision and then rapidly dissected from the surrounding structures and weighted. Liver specimens were obtained and fixed in buffered $10 \%$ formaldehyde solution for 24 hours and processed for paraffin sections of 5 micron thickness. The sections were stained with Haematoxylin and Eosin and examined under light microscopy [19].

\subsection{Biochemical Analysis}

Blood samples were drown by cardiac puncture and centrifuged at $3000 \mathrm{rpm}$ for 15 minutes to harvest the serum with which the liver functions assessment were analyzed. The activities of Alanine aminotransferase(ALT), aspartate aminotransferase (AST) are measured in serum according to the methods described by Reitman and Frankel [20]. Serum alkaline phosphatase (ALP) activity was determined according to Kind et al. [21]. Serum total and direct bilirubin levels were determined according according to the methods described by Dangerfield and Finlayson [22]. Serum $\gamma$-GT activity was determined according to the method of Szas [23].

\subsection{Statistical Analysis}

The values were presented as means \pm SD of different groups. Differences between the mean values were estimated using one way ANOVA. The results were considered statistically significant when $\mathrm{p}<0.05$.

\section{Results}

Histologically, by light microscopic examination, the liver appeared with normal structure in all control groups (negative and positive control animals). The hepatocytes arranged in cell strands radiating from the central vein with intervening blood sinusoids which appeared to be lined by Kupffer cells. The hepatocytes appeared pentagonal and contained large nuclei. (Fig. 1).

In cadmium treated animals, there were severe structural damage in the liver. Most of hepatocytes appeared fused together forming eosinophilic syncytial masses. The hepatocytes appeared irregularly arranged with disorganization of hepatic architecture. The hepatocytes appeared large with light and foamy cytoplasm filled with numerous vacuole-like spaces. The nuclei appeared with pyknotic nuclei. The central vein appeared dilated and congested with massive hemorrhage extending to the nearby cells. Mild periductal fibrosis around bile duct in the portal area were observed. Also, there were focal degenerative and necrotic changes along with inflammatory cell infiltration. (Fig. 2\&3).

In animals co-administered with cadmium chloride and fenugreek seeds, the central vein appear more or less normal. The hepatocytes regained their normal organization and architecture (Fig. 4A).

In animals co-administration of aqueous extracts of rosemary to the $\mathrm{Cd}$ treated animals did not completely regain the hepatocytes to normal. The liver sections revealed mild cloudy swelling of hepatocytes, and very mild degenerative changes in hepatocytes. The central vein appear normal. The hepatocytes regained their normal organization and architecture (Fig. 4B).

In animals co-administered with cadmium chloride and cinnamon. The central vein appear normal. The hepatocytes regained their normal organization and architecture. (Fig. 4C).

Tables 1,2 shows the means and standard deviations for serum ALT, AST, ALP, and $\gamma$ - GT activities in control groups, cadmium chloride treated group and guinea pigs groups co-administrated of cadmium chloride with fenugreek, rosemary, and cinnamon. The levels of serum alanine aminotransferase (ALT), aspartate aminotransferase (AST), alkaline phosphatase (ALP), and $\gamma$-glutamyltransferase $(\gamma$ GT) activities were elevated in cadmium chloride treated animals compared with the control groups with statistically significant differences $(\mathrm{p}<0.05)$. The enzyme activities in the co-administration of cadmium chloride with fenugreek, rosemary and cinnamon were decreased with statistically significant differences $(\mathrm{p}<0.05)$ (Figs. 5, 6, 7\&8).

Table 3 shows the bilirubin levels of control groups, experimental animals. The levels of serum total and direct bilirubin were elevated in cadmium chloride treated animals compared with the control groups with statistically significant differences $(p<0.05)$. The levels of serum total and direct bilirubin in the co-administration of cadmium chloride with fenugreek, rosemary and cinnamon were decreased with statistically significant differences $(\mathrm{p}<0.05)$ (Figs. 9\&10).

Regarding the changes in body and relative liver weight of the animals in the present study, the body weight at the end of the experiment decreased in the cadmium chloride treated animals compared with the control groups with statistically significant differences $(p<0.05)$. The weight increased in co-administered cadmium chloride and fenugreek seeds, cadmium chloride and rosemary and cadmium chloride and cinnamon with significant differences $(p<0.05)$ from the cadmium chloride treated group. The relative liver weight increased in cadmium chloride treated group as compared with the control group with statistically significant differences $(\mathrm{p}<0.05)$. The relative liver weight decreased in co-administered cadmium chloride and fenugreek seeds, cadmium chloride and rosemary and cadmium chloride and cinnamon with significant differences (Table 4 and Figs 11\&12). 


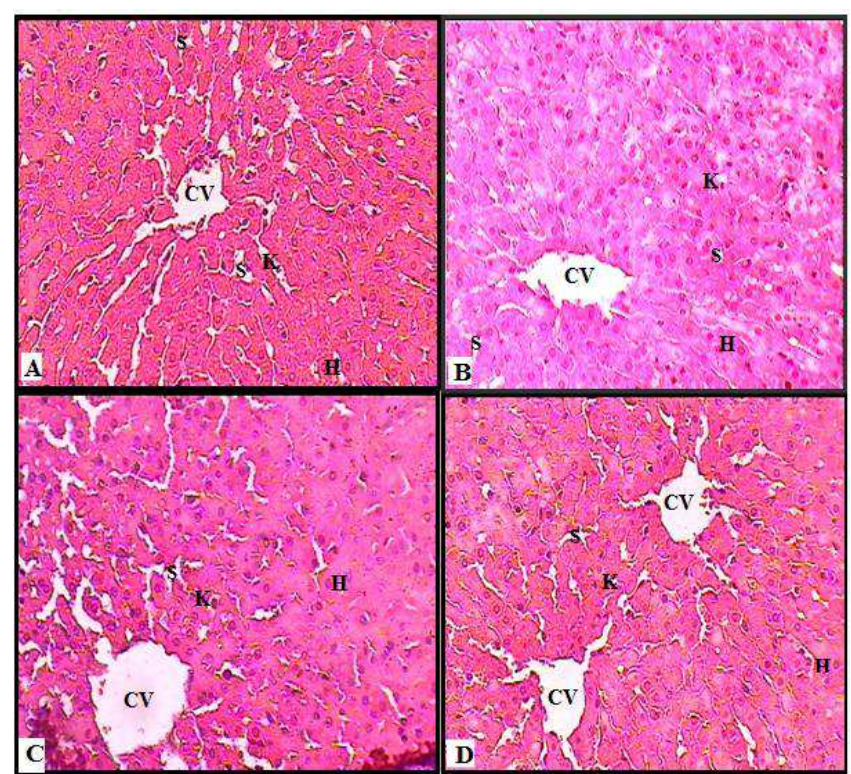

Fig 1. Light micrograph of sections in the liver control guinea pigs; A: negative control (administered saline), B: positive control (administered fenugreek only), C: positive control (administered rosemary only), $D$ : positive control (administered cinnamon only); Central vein (CV); Kupffer cells (K); Hepatocytes (H); Sinusoids (S). (Haematoxylin \&Eosin $\times 400$ )

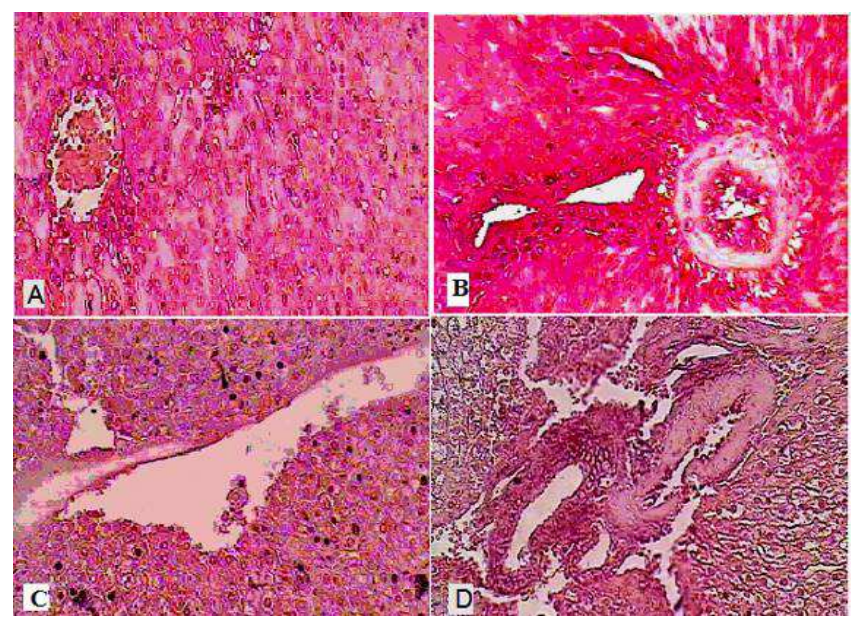

Fig 2. Light micrograph of sections in the liver of cadmium administrated group presenting; A: wide spread necrobiotic changes in the hepatocytes and focal area of coagulative necrosis of hepatocytes surrounded by inflammatory cells. B: Most of hepatocytes appeared fused together forming eosinophilic syncytial masses with scattered necrotic cells. C: Marked vacuolar degeneration mainly hydropic degeneration. Marked necrosis of hepatocytes, that appeared deeply esinophilic, and some with pyknotic nuclei. D: Marked vacuolar degeneration of hepatocytes mainly hydropic degeneration as well as marked fibrosis around the portal triad structures. (Haematoxylin \& Eosin $\times 400$ )

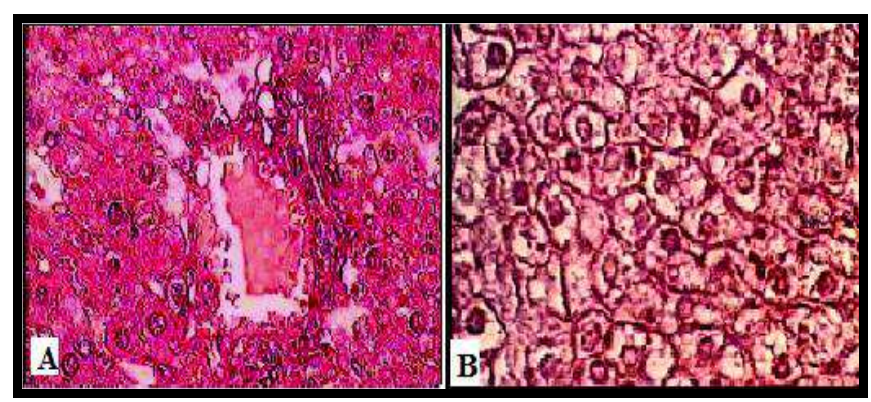

Fig 3. Light micrograph of sections of a higher magnification in the liver of cadmium treated guinea pigs. A: Marked hepatocellular necrosis specially in the pericentral area. These necrotic cells appeared homogenous structurless with degenerated nuclei and large number without nuclear structures, and the central vein appeared congested with massive hemorrhage extending to the nearby cells. B: Marked vacuolar degeneration mainly hydropic degeneration. (Haematoxylin \& Eosin $\times 1000$ )
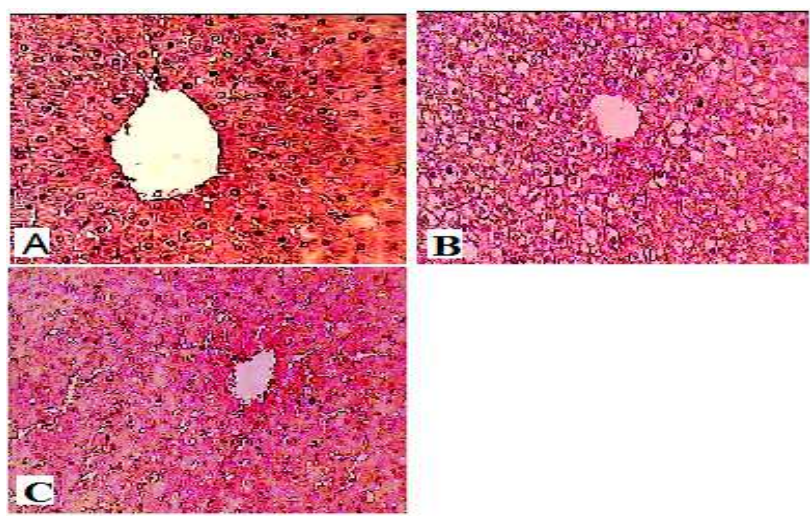

Fig 4. Light micrograph of a sections in the liver of cadmium treated guinea pigs; A: co-administered fenugreek. The central vein appear more or less normal. The hepatocytes regained their normal organization and architecture. B: Co-administered rosemary showing normal central vein, normal organization of hepatocytes with mild degenerative changes as cloudy swelling and hydropic degeneration with eccentric nuclei of some hepatocytes. C: Co-administered cinnamon. The central vein appear normal. The hepatocytes regained their normal organization and architecture. (Haematoxylin \&Eosin $\times 400$ )

Table 1. Effect of fenugreek seeds, rosemary, and cinnamon on the serum alanine aminotransferase, and aspartate aminotransferase activities of cadmium chloride treated male guinea pigs in different groups .

\begin{tabular}{lll}
\hline \multirow{2}{*}{ Group } & ALT (U/L) & AST (U/L) \\
\cline { 2 - 3 } & Mean \pm SD & Mean \pm SD \\
\hline Control & $61.83 \pm 4.71$ & $93.33 \pm 6.51$ \\
Fenugreek seeds & $79.83 \pm 4.02^{\mathrm{a}}$ & $112.33 \pm 1.83^{\mathrm{a}}$ \\
Rosemary & $82.17 \pm 2.68^{\mathrm{a}}$ & $116.17 \pm 1.80^{\mathrm{a}}$ \\
Cinnamon & $78.33 \pm 1.83^{\mathrm{a}}$ & $108.83 \pm 2.68^{\mathrm{a}}$ \\
Cadmium chloride & $145.17 \pm 11.01^{\mathrm{a}}$ & $174.82 \pm 9.01^{\mathrm{a}}$ \\
Cadmium chloride + Fenugreek & $95.33 \pm 7.88^{\mathrm{ab}}$ & $132.18 \pm 4.23^{\mathrm{ab}}$ \\
Cadmium chloride + Rosemary & $92.00 \pm 3.83^{\mathrm{ab}}$ & $123.16 \pm 3.94^{\mathrm{ab}}$ \\
Cadmium chloride + Cinnamon & $98.67 \pm 3.58^{\mathrm{ab}}$ & $128.00 \pm 3.67^{\mathrm{ab}}$ \\
\hline
\end{tabular}

a: Significant differences as compared with control group $(\mathrm{P}<0.05)$,

$\mathrm{b}$ : Significant differences as compared with cadmium chloride treated group $(\mathrm{P}<0.05)$. All data are mean of 6 individuals. 


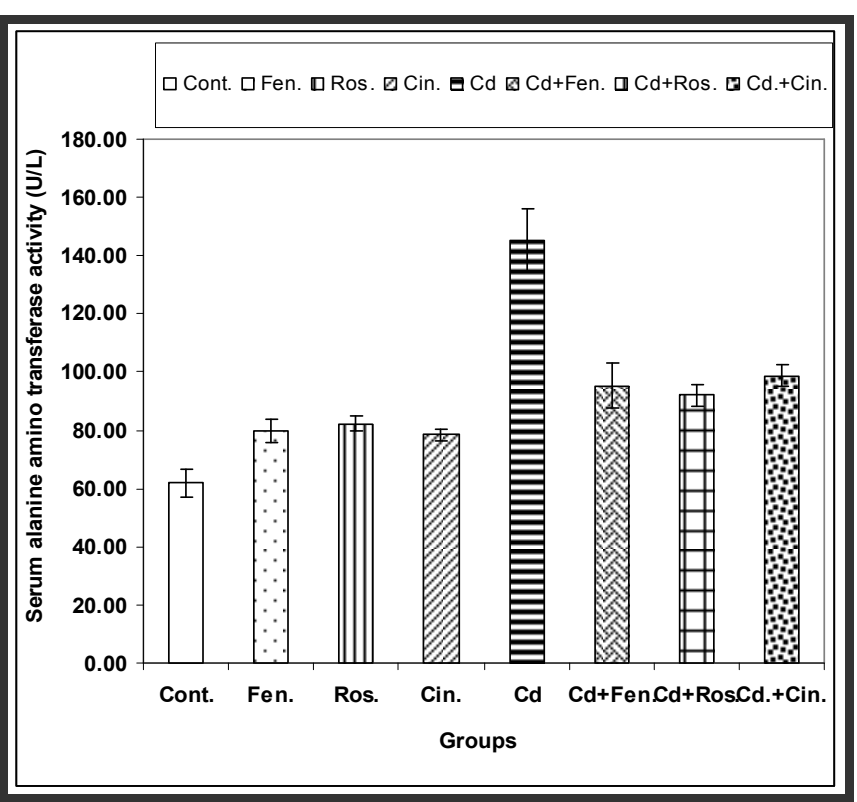

Fig 5. The serum alanine aminotransferase (ALT) activity in different animals groups. The serum ALT activity is the highest in cadmium chloride treated group $(\mathrm{Cd})$ in comparison with control groups (normal control, fenugreek seeds treated (Fen.), rosemary treated (Ros.), and cinnamon treated (Cin.). The serum ALT activity shows declining in co-administered cadmium chloride and fenugreek seeds (Cd+Fen.), cadmium chloride and rosemary $(C d+R o s$.$) , and cadmium chloride and cinnamon treated$ (Cd+Cin.)

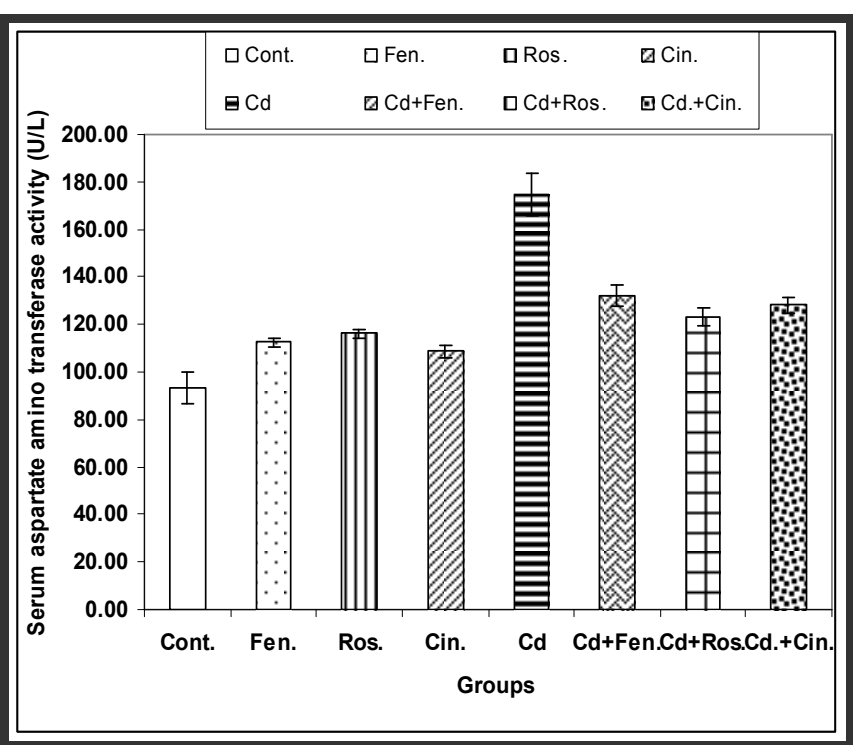

Fig 6. The serum aspartate aminotransferase(AST) activity in different animals groups. The serum AST activity is the highest in cadmium chloride treated group $(\mathrm{Cd})$ in comparison with control groups (normal control, fenugreek seeds treated (Fen.), rosemary treated (Ros.), and cinnamon treated (Cin.). The serum AST activity shows declining in co-administered cadmium chloride and fenugreek seeds (Cd+Fen.), cadmium chloride and rosemary $(C d+R o s$.$) , and cadmium chloride and cinnamon treated$ $(C d+$ Cin. $)$

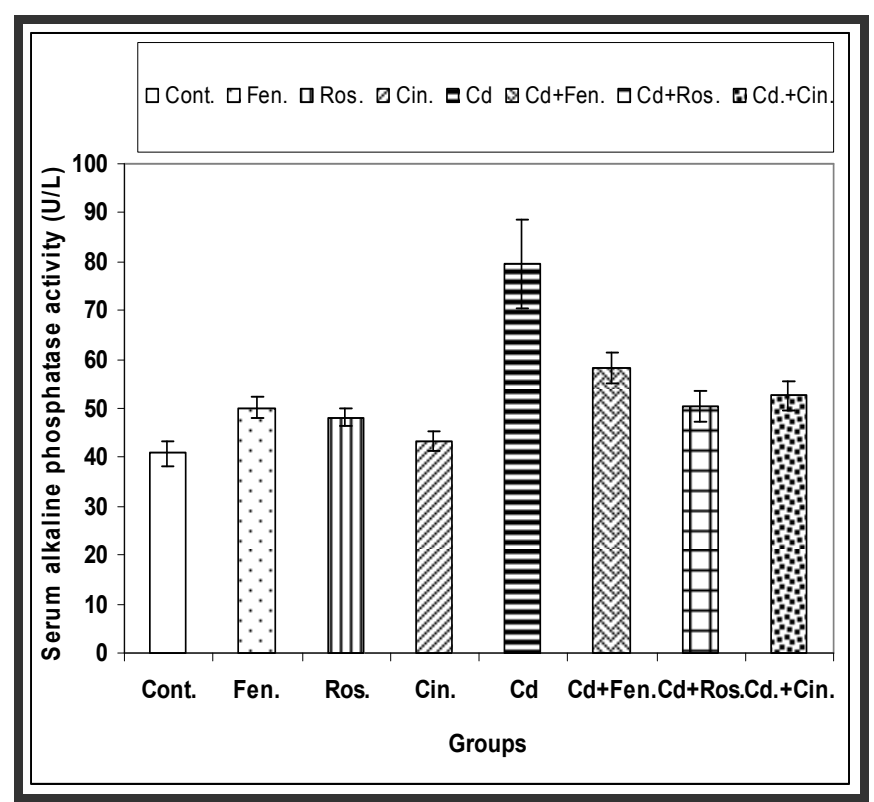

Fig 7. The serum alkaline phosphatase activity $(A L P)$ in different animals groups. The serum ALP activity is the highest in cadmium chloride treated group $(C d)$ in comparison with control groups (normal control, fenugreek seeds treated (Fen.), rosemary treated (Ros.), and cinnamon treated (Cin.). The serum ALP activity shows declining in co-administered cadmium chloride and fenugreek seeds $(\mathrm{Cd}+\mathrm{Fen}$.), cadmium chloride and rosemary $(\mathrm{Cd}+$ Ros. $)$, and cadmium chloride and cinnamon treated $(\mathrm{Cd}+\mathrm{Cin}$.

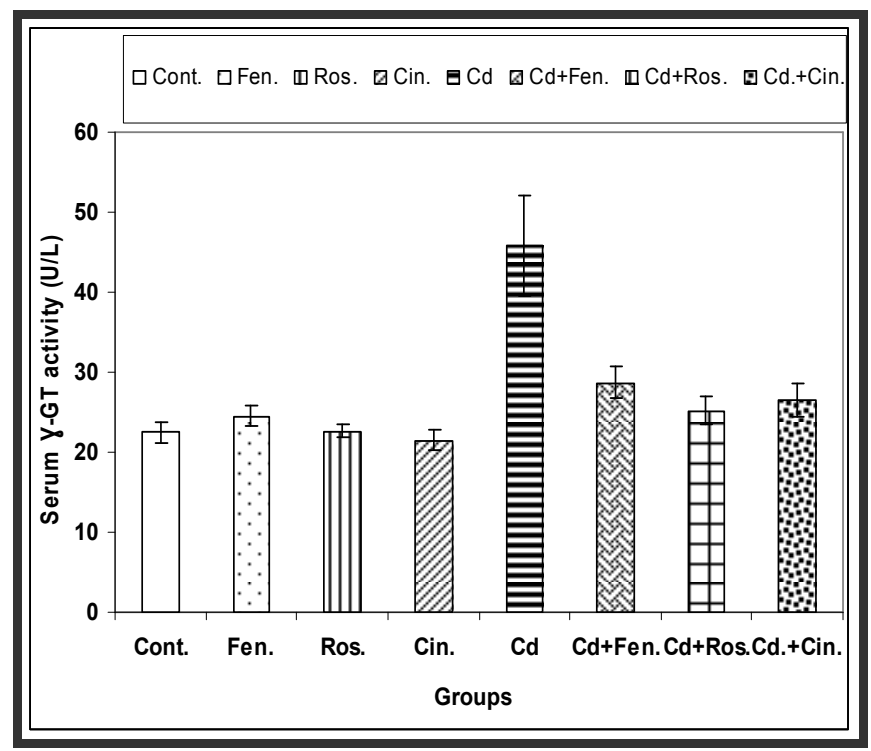

Fig 8. The serum $\gamma$ - glutamyltransferase $(\gamma-G T)$ activity in different animals groups. The serum $\gamma-G T$ activity is the highest in cadmium chloride treated group (Cd) in comparison with control groups (normal control, fenugreek seeds treated (Fen.), rosemary treated (Ros.), and cinnamon treated (Cin.). The serum $\gamma-$ GT activity shows declining in co-administered cadmium chloride and fenugreek seeds $(\mathrm{Cd}+\mathrm{Fen}$.), cadmium chloride and rosemary (Cd+Ros.), and cadmium chloride and cinnamon treated $(\mathrm{Cd}+\mathrm{Cin}$.) 
Table 2. Effect of fenugreek seeds, rosemary, and cinnamon on the serum alkaline phosphatase, and $\boldsymbol{\gamma}$-glutamyltransferase activities of cadmium chloride treated male guinea pigs in different groups .

\begin{tabular}{lll}
\hline \multirow{2}{*}{ Group } & ALP $(\mathbf{U} / \mathbf{L})$ & X-GT $(\mathbf{U} / \mathbf{L})$ \\
\cline { 2 - 3 } & Mean \pm SD & Mean \pm SD \\
\hline Control & $40.83 \pm 2.48$ & $22.50 \pm 1.25$ \\
Fenugreek seeds & $50.17 \pm 2.27^{\mathrm{a}}$ & $24.50 \pm 1.24$ \\
Rosemary & $48.17 \pm 1.87^{\mathrm{a}}$ & $22.67 \pm 0.72$ \\
Cinnamon & $43.33 \pm 2.03$ & $21.50 \pm 1.26$ \\
Cadmium chloride & $79.50 \pm 9.01^{a}$ & $45.83 \pm 6.18^{\mathrm{a}}$ \\
Cadmium chloride + Fenugreek & $58.33 \pm 3.21^{\mathrm{ab}}$ & $28.67 \pm 2.03^{\mathrm{ab}}$ \\
Cadmium chloride + Rosemary & $50.33 \pm 3.20^{\mathrm{ab}}$ & $25.17 \pm 1.75^{\mathrm{b}}$ \\
Cadmium chloride + Cinnamon & $52.66 \pm 3.03^{\mathrm{ab}}$ & $26.50 \pm 2.05^{\mathrm{ab}}$ \\
\hline
\end{tabular}

a: Significant differences as compared with control group $(\mathrm{P}<0.05)$, b: Significant differences as compared with cadmium chloride treated group $(\mathrm{P}<0.05)$. All data are mean of 6 individuals.

Table 3. Effect of fenugreek seeds, rosemary, and cinnamon on total and direct bilirubin in the serum of cadmium treated male guinea pigs in different groups .

\begin{tabular}{lll}
\hline \multirow{2}{*}{ Group } & $\begin{array}{l}\text { Total bilirubin }(\mathrm{mg} / \\
\text { dl) }\end{array}$ & Direct bilirubin $(\mathbf{m g} / \mathbf{d l})$ \\
\cline { 2 - 3 } & Mean \pm SD & Mean \pm SD \\
\hline Control & $0.0313 \pm 0.0014$ & $0.0182 \pm 0.0028$ \\
Fenugreek seeds & $0.0353 \pm 0.0012^{\mathrm{a}}$ & $0.0208 \pm 0.0015$ \\
Rosemary & $0.0327 \pm 0.0028$ & $0.0207 \pm 0.0010$ \\
Cinnamon & $0.0340 \pm 0.0033$ & $0.0238 \pm 0.0017$ \\
Cadmium chloride & $0.0847 \pm 0.0096^{\mathrm{a}}$ & $0.0532 \pm 0.0053^{\mathrm{a}}$ \\
$\begin{array}{l}\text { Cadmium chloride } \\
+ \text { Fenugreek }\end{array}$ & $0.0495 \pm 0.0011^{\mathrm{ab}}$ & $0.0393 \pm 0.0011^{\mathrm{ab}}$ \\
$\begin{array}{l}\text { Cadmium chloride } \\
+ \text { Rosemary }\end{array}$ & $0.0465 \pm 0.0010^{\mathrm{ab}}$ & $0.0350 \pm 0.0009^{\mathrm{ab}}$ \\
$\begin{array}{l}\text { Cadmium chloride } \\
+ \text { Cinnamon }\end{array}$ & $0.0478 \pm 0.0013^{\mathrm{ab}}$ & $0.0382 \pm 0.0008^{\mathrm{ab}}$ \\
\hline
\end{tabular}

a : Significant differences as compared with control group $(\mathrm{P}<0.05)$, b : Significant differences as compared with cadmium chloride treated group $(\mathrm{P}<0.05)$. All data are mean of 6 individuals.

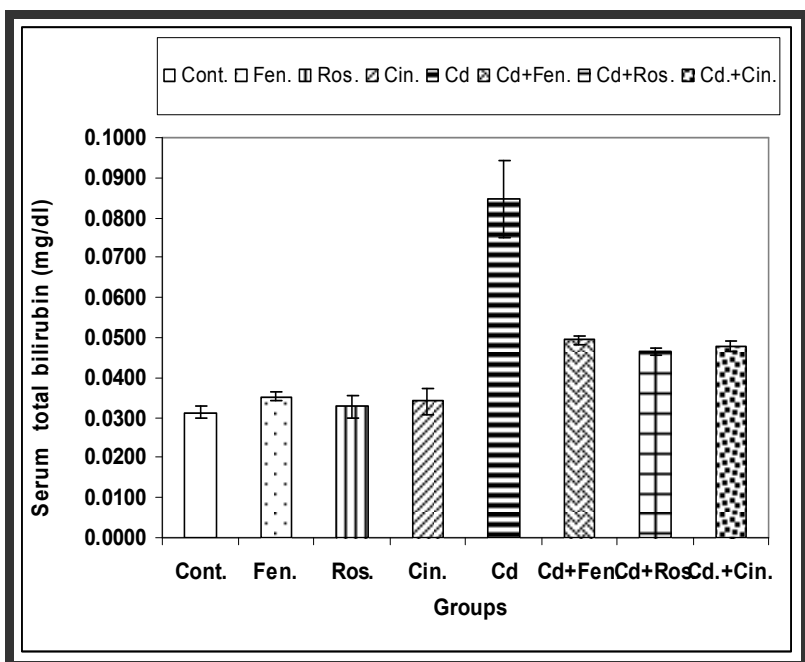

Fig 9. The serum total bilirubin level in different animals groups. The serum total bilirubin levels is the highest in cadmium chloride treated group (Cd) in comparison with control groups (normal control, fenugreek seeds treated (Fen.), rosemary treated (Ros.), and cinnamon treated (Cin.). The serum total bilirubin level shows declining in co-administered cadmium chloride and fenugreek seeds (Cd+Fen.), cadmium chloride and rosemary $(C d+$ Ros.), and cadmium chloride and cinnamon treated $(C d+C i n)$.

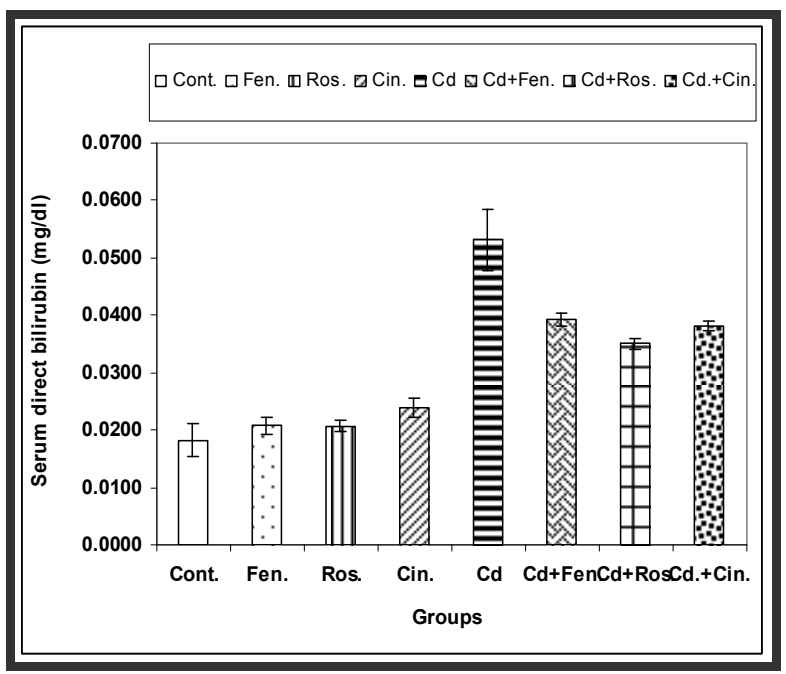

Fig 10. The serum direct bilirubin level in different animals groups. The serum direct bilirubin level is the highest cadmium chloride treated group (Cd) in comparison with control groups (normal control, fenugreek seeds treated (Fen.), rosemary treated (Ros.), and cinnamon treated (Cin.). The serum direct bilirubin level shows declining in co-administered cadmium chloride and fenugreek seeds $(C d+F e n$.$) , cadmium chloride and rosemary$ $(C d+R o s$.$) , and cadmium chloride and cinnamon treated (C d+C i n$.

Table 4. Effect of fenugreek seeds, rosemary, and cinnamon on body weight and relative liver weight of cadmium chloride treated male guinea pig in different groups.

\begin{tabular}{lll}
\hline Group & $\begin{array}{c}\text { Body weight } \\
(\mathbf{g})\end{array}$ & $\begin{array}{c}\text { Relative liver weight } \\
\text { (gm/100 gm of body weight) }\end{array}$ \\
\hline Control & Mean \pm SD & Mean \pm SD \\
\hline Fenugreek seeds & $510 \pm 15.8$ & $3.19 \pm 0.26$ \\
Rosemary & $477 \pm 9.8^{\mathbf{a}}$ & $3.66 \pm 0.20$ \\
Cinnamon & $471 \pm 8.5^{\mathbf{a}}$ & $3.48 \pm 0.23$ \\
Cadmium chloride & $473 \pm 21.5$ & $3.65 \pm 0.21$ \\
Cadmium chloride & $339 \pm 15.2^{\mathrm{a}}$ & $5.58 \pm 0.41^{\mathrm{a}}$ \\
+ Fenugreek & & \\
$\begin{array}{l}\text { Cadmium chloride } \\
+ \text { Rosemary }\end{array}$ & $501 \pm 7.8^{\mathbf{b}}$ & $4.23 \pm 0.29^{\mathrm{ab}}$ \\
$\begin{array}{l}\text { Cadmium chloride } \\
+ \text { Cinnamon }\end{array}$ & $443 \pm 7.5^{\mathrm{ab}}$ & $4.10 \pm 0.24^{\mathrm{ab}}$ \\
\hline
\end{tabular}

a : Significant differences as compared with control group $(\mathrm{P}<0.05)$ b : Significant differences as compared with cadmium chloride treated group $(\mathrm{P}<0.05)$. All data are mean of 6 individuals.

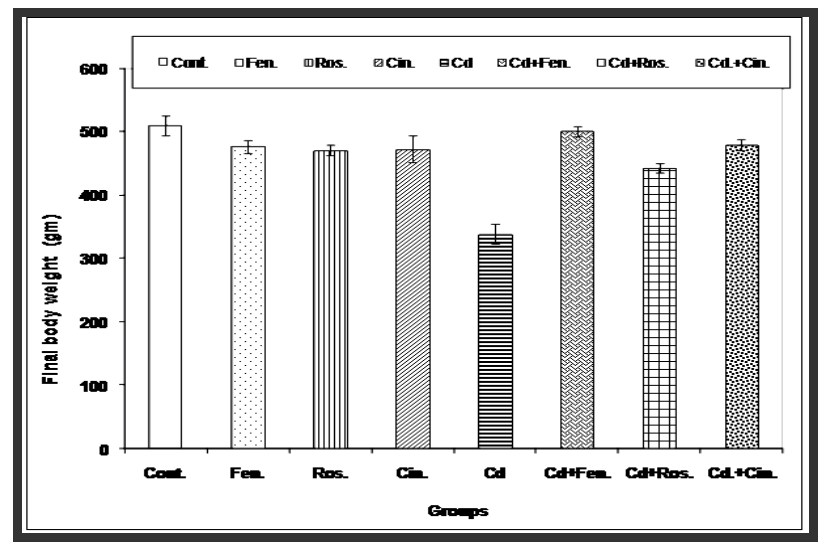

Fig 11. The body weight in different animals groups. The body weight decreased in cadmium chloride treated group (Cd) in comparison with control groups (normal control, fenugreek seeds treated (Fen.), rosemary treated (Ros.), and cinnamon treated (Cin.). The body weight increases in co-administered cadmium chloride and fenugreek seeds $(\mathrm{Cd}+\mathrm{Fen}$.) cadmium chloride and rosemary (Cd+Ros.), and cadmium chloride and cinnamon treated (Cd+Cin.) 


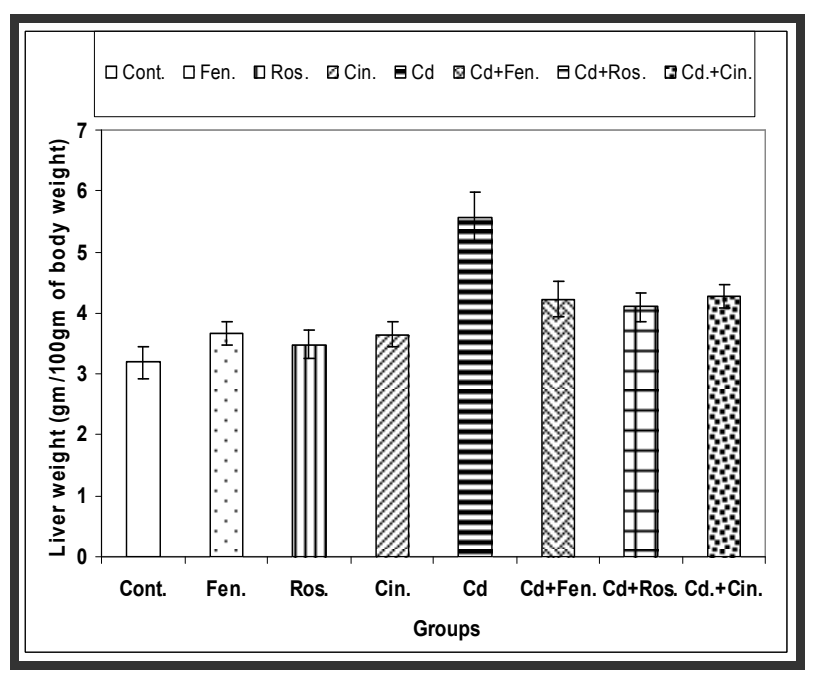

Fig 12. The liver weight in different animals groups. The liver weight increases in cadmium chloride treated group (Cd) in comparison with control groups (normal control, fenugreek seeds treated (Fen.), rosemary treated (Ros.), and cinnamon treated (Cin.). The weight declines in co-administered cadmium chloride and fenugreek seeds $(\mathrm{Cd}+\mathrm{Fen}$.), cadmium chloride and rosemary (Cd+Ros.), and cadmium chloride and cinnamon treated $(\mathrm{Cd}+\mathrm{Cin}$.

\section{Discussion}

In the present study, the cadmium had adverse effects on the liver. Histologically, the hepatocytes appeared irregularly arranged with disorganization of hepatic architecture. The hepatocytes appeared large with light and foamy cytoplasm filled with numerous vacuole-like spaces. The nuclei appeared pyknotic nuclei. The central vein appeared dilated and congested with massive hemorrhage extending to the nearby cells. Mild periductal fibrosis around bile duct in the portal area were observed. Also, there were focal degenerative and necrotic changes along with inflammatory cell infiltration. These results indicated that cadmium at the administered dose in the study produced severe oxidative damage in liver. This is in agreement with many authors who reported the toxicity of $\mathrm{Cd}$ on the liver [24-27]. Mahran et al. [28] found that the $\mathrm{Cd}$ can cause vacuolar degeneration and increased density of nuclear chromatin with very compact nuclear structure found in hepatocytes. In addition to mononuclear cell infiltrations and necrosis of single cells were also observed. Gathwan et al.[29] found that the cadmium can cause swelling and massive fatty degeneration in hepatocytes and large vacuoles in cytoplasm with pykontic nuclei.

Interpretation of vacuolar formation following chemical treatments has been subjected to wide speculation by many investigators. Robbins and Angell [30] regarded such vacuolation to represent primary morphologic response to many forms of cell injury. They also attributed it to the noxious effects of treatment on the cell membranes, both structurally and functionally, causing marked disturbances in its permeability system. This presumably leads to enhanced imbibition of water into the cells. When it sufficiently accumulates in the cells, such intracellular water produced clear cytoplasmic vacuoles indication the occurrence of the pathologic symptoms commonly referred to as hydropic degeneration or fatty degeneration caused by lipid abundance in such instance.

Many authors explained the mechanisms of $\mathrm{Cd}$ induced hepatotoxicity. Previous studies has been suggested that cadmium disturbs membranes integrity [31], generates reactive oxygen species [32,33], which cause oxidative damage to lipid contents of membranes [34], and involves cytotoxic and inflammatory mediators [35] in the liver $[4,36,37]$.

Over production of ROS normally induces oxidative stress unless it was scavenged with endogenous antioxidants. Thus, over production of ROS could be attributed to the depletion of antioxidants or to the direct action of $\mathrm{Cd}$ on peroxidation reaction and iron-mediated peroxidation [38]. Primary injury of cells resulting from binding of $\mathrm{Cd}$ to sulthydryl groups in mitochondria and secondary injury initiated by the activation of kupffer cells have also been mentioned as possible mechanisms of toxic effect of $\mathrm{Cd}$ on the liver [35]. Inactivation of sulthydryl groups causes oxidative stress, mitochondrial permeability transition and mitochondrial dysfunction [39]. It is also suggested that kupffer cells release proinflammatory cytokines and chemokines which stimulate the migration and accumulation of neutrophils and monocytes in the liver [40]. Dudley [40] also suggested that hepatocytes injury may be caused by ischemia due to sinusoidal endothelial cell dysfunction. Cd has been found to accumulate in endothelial cells leading to necrosis and denudation of hepatic sinusoids. The hepatotoxicity of cadmium has also been attributed to the formation of toxic metabolites when it is activated by hepatic cytochrome $\mathrm{P} 450$ [41] to a highly active metabolite $\mathrm{N}$-acelyl-P-benzooquinone imine [42]. Furthermore, interference with essential metals could be one of the mechanisms employed by $\mathrm{Cd}$ mediated toxicological effects $\mathrm{Cd}$ forms covalent and ionic bonds with atoms of sulfur, oxygen and hydrogen present in the sulfhydryl groups, disulfide, carboxyl, imidazole or multiple amino compounds present in the cells, causing significant disruption of their homeostasis [43].

Biochemically, in the present study, treatment of guinea pigs with cadmium chloride caused a significant increase of the activities of serum AST, ALT, ALP , $\gamma$-GT and the levels of total and direct bilirubin. These elevation in marker enzymes indicating oxidative injury in liver. Similarly, Renugadevi, and Prabu [4] found that the levels of serum hepatospecific enzymes such as AST, ALT, ALP, $\gamma$-GT and the level of total bilirubin were significantly increased in cadmium treated rats. Cadmium associated hepatotoxicity manifested through impaired functions of hepatic biomarkers (transaminases) [25,26]. These results may indicate degenerative changes and hypofunction of liver $[44,45]$ as well as hepatic cell necrosis [46] which increase the releasing of these enzymes in the blood stream [47]. The tissue peroxidation induced by $\mathrm{Cd}$ lead to liver dysfunction which was reflected as alteration in various functional markers in serum. This alteration was significant increase in 
ALT level indicating hepatotoxicity [4,25]. The specific location of ALP within both sinusoidal and bile canalicular membranes accounts for the more predominant elevations in certain disorders [48]. The increase in alkaline phosphatase activities represent general hepatic toxicity [49]. Serum $\gamma$-GT, a membrane bound enzyme are the well-known indicators of cell and tissue damage by toxic substances and their levels are also substantially increased in $\mathrm{Cd}$ treated rats [4]. The serum level of total bilirubin in the present study has also been found to be increased in cadmium treated animals, which is in agreement with the result of Renugadevi and Prabu[4], and Liss et al.[50] who suggested that increase in serum bilirubin is a clear marker of hepatic dysfunction. It is well established that cadmium intoxication significantly elevated the serum hepatic marker enzymes and total bilirubin $[4,51]$.

In the present study, the body weight of the animals decreased and the relative liver weight increased at the end of the experiment in cadmium chloride treated group. This is in accordance with Prabu et al. [52] who found that oral administration of cadmium chloride resulted in decrease in the body weight and increase of the relative liver weight. Also, the body weight decreased [25,29], and the liver weight increased in cadmium treated male rats, and mice [53]. The decreased body weight explained by Kaltreider et al. [54] who found that exposure to low level of heavy metals impairs the glucocorticoid system. The glucocorticoid hormones play a vital role in glucose regulation as well as carbohydrate, lipid and protein metabolism. Dysfunction in the glucocorticoid system has been linked to weight gain/loss. On the other hand, the present result disagree with the results obtained by Gathwan et al. [29] who found a decrease of the liver weight with increase of dose in mice treated with different doses of cadmium chloride.

Co-administration of aqueous extracts of fenugreek seeds, and cinnamon with cadmium chloride significantly regained their normal organization and architecture of the hepatocytes, and the central vein appeared normal. On the other hand, co-administration of aqueous extracts of rosemary to the $\mathrm{Cd}$ treated animals did not completely regain the hepatocytes to normal. Hepatocytes were enlarged and had light and foamy cytoplasm filled with numerous vacuole-like spaces, and mild degenerative changes. Similarly, Eidi et al. [11] found that cinnamon extract markedly reduced the toxicity of $\mathrm{CCl} 4$ and preserved the histoarchitecture of the liver tissue to near normal. Thus, the results suggest that cinnamon extract acts as a potent hepatoprotective agent against $\mathrm{CCl} 4$ induced hepatotoxicity in rats. The hepatoprotective effects of cinnamon extract may be due to both an increase in the activity of the antioxidant-defense system and an inhibition of lipid peroxidation.

Cellular damage caused by cadmium exposure can be prevented by free radical scavengers or antioxidants, which further strengthens the hypothesis that free radicals play a key role in cadmium toxicity. Antioxidants are the frontline of defense against free radicals [55]. The present study is supported by other studies shown that the livers of rats treated with extract of fenugreek seeds showed a significant attenuation from $\mathrm{CCl} 4$-induced liver damage as evident from normal hepatocytes with well-defined nuclei. The improvement of histological changes in the liver are well correlating with the biochemical estimations. These results suggest that the extract of fenugreek seeds has potential clinical applications for treating liver disorders [56,57].

In the present study, co-administration of aqueous extracts of fenugreek seeds, rosemary, and cinnamon with cadmium chloride reduced the enzyme activities towards the control values. Kumar and Bhandari [58] demonstrated that the activities of serum ALT and AST were increased in rats treated with monosodium glutamate. Administration of aqueous Trigonella foenum-graecum seeds significantly reduced the elevated ALT and AST levels, which could be attributed to the protective effect on hepatic tissues. Das [57] reported that administration of extract of fenugreek seeds in $\mathrm{CCl} 4$ treated rats caused reduction in Serum ALT, AST, ALP levels.

Administration of aqueous extracts of fenugreek seeds, and cinnamon along with $\mathrm{Cd}$, showed a good protective effect by restoration of biochemical profiles in the hepatic functional indicators in serum. This was also well correlated with near normal histological architecture in the liver. This is in agreement with AL-Shaikh [59] who found that oral administration of cinnamon oil produce significant restores liver function and normalize the histological and biochemical abnormalities caused by diabetes in alloxan induced diabetic rats, this may be due to antioxidant effect of this herb. Administration of naringenin attenuated cadmium-induced hepatotoxicity as shown by the decreased levels of AST, ALT, ALP, GGT, and reduced level of serum bilirubin, thus offering protection against $\mathrm{Cd}$ toxicity in rats [4].

Administration with cinnamon extracts significantly reduced the impact of $\mathrm{CCl} 4$ toxicity on the serum markers of liver damage, aspartate aminotransferase, alanine aminotransferase and alkaline phosphatase [11]. A water extract of Fenugreek seeds concurrently during 60 days of alcohol ingestion was associated with a reduction in the rise of oxidation and liver enzymes noted in the serum of rats given ethanol alone, suggesting protective effects [60].

It was observed that some antioxidants, extracts of plant origin including Solanum tuberosum, Calycopteris floribunda and Hibiscus sabdariffa, and chemical substances of animal origin including honey and camel milk were reported to have ameliorated $\mathrm{Cd}$ induced hepatotoxicity through normalization of biochemical parameters and histopathological changes induced by cadmium [26]. The administration of naringenin in cadmium treated rats counteracted the oxidative hepatic dysfunction attributed by cadmium. Treatment with naringenin appreciably reduced the abnormal changes induced by cadmium and restored the biomarkers value of oxidative stress and hepatotoxicity towards near normal. This was sustained by the restoration in the levels of hepatic serum marker enzymes. Hepatoprotective nature of naringenin against cadmium was further supported by the improvement in the histopathological changes occasioned by cadmium [4]. 
Rosemary pretreatment has also shown protective effects as judged by the lower activities of serum aminotransferase, the marked recovery of normal liver histological architecture and by the reduced level of MDA in comparison to azathioprine -treated group[13]. Aqueous extract of rosemary have been reported to have hepatoprotective effects against CCL4-induced liver damage [61] and to prevent the increase in aminotransferase enzymes and histopathology changes induced by CCL4 [62].This can be explained that, aqueous extract of rosemary has significantly decreased the release of aspartate aminotransferase, thus confirming the antihepatotoxic action of rosemary extract [63]. The active constituents of rosemary like carnosol, carnosic acid, caffeic acid, rosmarinic acid, ursolic acid, different diterpenes, phenols and flavonoids are reported to have antioxidant, antimutagenic, radioprotective properties [64]. It has been shown that rosemary extract and its antioxidant compounds inhibit free radicals generations in vivo [65]. Rosmarinic acid [66], diterpenoids such as carnosic acid, carnosol, rosmanol, epirosmanol [67], carotenoid, and alpha-tocopherol [68] have been documented as the principal antioxidant constituents of rosemary extracts. The chemopreventive action of rosemary can alternatively be mediated through the induction of detoxification enzymes [62,69].

Phytochemical screening of cinnamon bark has revealed the presence of flavonoids, glycosides, coumarins, alkaloids, anthraquinone, steroids, tannins, and terpenoids [70]. Phytoconstituents like the flavonoids [71], triterpenoids [72], saponins [73], and alkaloids [74] are known to possess hepatoprotective activity. Numerous studies have suggested that flavonoids commonly function as antioxidants and may protect plants against oxidative stress caused by suboptimal environmental conditions $[75,76]$. The antioxidant capacity of flavones is attributed to the high reactivity of the hydroxyl substituent, with the number of hydroxyl groups on the B-ring being correlated with ROS scavenging capability [77].

Co-administration of aqueous extracts of fenugreek seeds, rosemary, and cinnamon, significantly improves the body and liver weight. This is in agreement with many authors who reported co- administration of ethanolic extract of Tribulus terrestris or vitamin E with cadmium exposure showed a significant increase in body weights compared to cadmium intoxicated rats, [25]. The altered body weight and liver weight parameters in rats intoxicated with cadmium were recovered to near normal levels, when rats treated with piper betle leaf extract (PBE), due to the antioxidant effects of polyphenols found in $\mathrm{PBE}$ [52].

\section{Conclusion}

It can be concluded that, the cadmium has adverse effects on the liver. Aqueous extracts of different natural materials as fenugreek, rosemary and cinnamon were able to attenuate these effects. So, the populations of high risk to cadmium should be advised to take one of these materials.

\section{References}

[1] Grattagliano I, Bonfrate L, Catia VD, Wang HH, Wang $\mathrm{DQH}$ and Portincasa P: Biochemical mechanisms in drug-induced liver injury. World J Gastroenterol 2009;5: $4865-4876$

[2] World Health Organization (WHO): Cadmium: Air Quality Guidelines, 2nd ed., World Health Organization, Copenhagen, Denmark, 2000

[3] Jarup L: Hazards of heavy metal contamination. Br Med Bull 2003; 68: 167-182

[4] Renugadevi J and Prabu, SM: Cadmium-induced hepatotoxicity in rats and the protective effect of naringenin. Exp Toxicol Pathol 2010;62: 171-181

[5] Heeba GH, and Abd-Elghany MI: Effect of combined administration of ginger (Zingiber officinale roscoe) and otorvastatin on the liver of rats. Phytomedicine 2010;17:1076-1081

[6] Ho C, Ferrara T, Chin Q, Rosen R and Huang M: Phytochemicals in teas and rosemary and their cancer preventive properties in: food phytochemicals for cancer prevention. American Chemical Society, Washington, DC, 1994, pp.2-19

[7] Flammang AM, Cifone MA, Ereson GL and Stankowskci LF Genotoxicity testing of fenugreek extract. J Food Chem Toxicol 2004;42: 205-208

[8] Basch E, Ulbricht C, Kuo G, Szapary P and Smith M: Therapeutic application of fenugreek. Altern Med Rev 2003; 8(1): $20-27$

[9] Aruoma O, Halliwell B, Aeschbach R, Loligers J: Antioxidant and pro-oxidant properties of active rosemary constituents: carnosol and carnosic acid. Xenobiotica 1992;22: $257-268$

[10] Moselhy SS and Ali HKH: Hepatoprotective effect of Cinnamon extracts against carbon tetra-chloride induced oxidative stress and liver injury in rats. Biol Res 2009;42: 93-98

[11] Eidi A, Mortazavi P, Bazargan M, and Zaringhalam J: Hepatoprotective activity of cinnamon ethanolic extract against $\mathrm{CCl} 4$-induced liver injury in rats. Excli J 2012;11:495-507.

[12] Kassim, H M: Effect of fenugreek seeds extract on liver cells and enzymes of male albino mice. Iraqi J Sci 2012;53(1): $62-67$

[13] Amin A and Hamza AA: Hepatoprotective effects of hibiscus, rosemarinus and salvia on azathioprine-induced toxicity in rats. Life Sci J 2005;77: 266-278

[14] Hasanein MA, Abdel Gawad SH and Abd El-Megeid AA: Effect of water extract prepared from green tea, black tea and cinnamon on obese rats suffering from diabetes. World Appl Sci J 2012; 20(7): 976-987

[15] Rajasekaran A and Periasamy M : Hepatoprotective effect of ethanolic leaf extract of Calycopteris floribunda $\mathrm{L}$ on cadmium induced hepatotoxicity in rats. Res J Pharmacol Biol Chem Sci 2012;3(3): 382-390 
[16] Dorman HJ, Peltoketo , Hiltunen R and Tikkanen MJ: Characterization of the antioxidants properties of de-odourised aqueous extracts from selected lamiaceae herbs. Food Chem 2003;83: 255-262

[17] Sakr SA and Lamfon HA: Protective effect of rosemary (Rosmarinus officinalis) leaves extracts on carbon tetrachloride-induced nephrotoxicity in albino rats. Life Sci J 2012;9(1): 779-785

[18] Flecknell PA: Laboratory Animal Anaesthesia. An Introduction for research workers and technicians. Academic Press, New York, 1996

[19] Ross MH, Reith EJ and Romrell LJ: Histology, A Text Atlas (2nd ed.) Baltimore. Williams \&Wilkins ,1989, pp.51- 84

[20] Reitman S, and Frankel A: Colorimetric method for determination of serum glutamate oxaloaectate and glutamic pyruvate transaminase. Amer J Clin Pathol 1957; 28: 56-58

[21] Kind PRN, King EJ, Varley H, Gowenlock AH, Bell M: Method of practical clinical biochemistry. Heinman, London, 1980, pp. 899-900

[22] Dangerfield WG and Finlayson R: Estimation of bilirubin in serum. J Clin Pathol 1953;6(3):173-177

[23] Szas G: Reaction rate method for gamma glutamyl transferase activity in serum. Clin Chem 1976;22: 2031-2055

[24] EL-Sokkary GH, Nafady AA, and Shabash EH: Melatonin administration ameliorates cadmium-induced oxidative stress and morphological changes in the liver of rat. Ecotoxicol Environ Safe 2010;73(3): 456-463

[25] Lakshmi GD, Kumar PR, Bharavi K, Annapurna P, Rajendar B, Patel PT, Kumar CSVS, and Rao GS: Protective effect of Tribulus terrestris $L$ on liver and kidney in cadmium intoxicated rats. Indian J Exper Biol 2012;50: 141-146

[26] Adikwu E, Deo O, and Geoffrey, OBP: Hepatotoxicity of cadmium and roles of mitigating agents. $\mathrm{Br} \mathrm{J}$ Pharmacol Toxicol, 2013;4(6): 222-231

[27] Zhai Q, Wang G, Zhao J, Liu X, Tian F, Zhang H, Chen W: Protective effects of Lactobacillus plantarum CCFM8610 against acute cadmium toxicity in mice. Appl Environ Micro 2013;79(5): 1508-1515

[28] Mahran AA, Osman HEH, Abd El-Mawla AMA,and Attia AM: Protective effect of zinc $(\mathrm{Zn})$ on the histology and histochemistry of liver and kidney of albino rat treated with cadmium. J Cytol Histol 2011;2 (4): 2-9

[29] Gathwan KH, Al Ameri QMA, Zaidan HK, Al Saadi AH, and Ewadh MJ: Heavy metals induce apoptosis in liver of mice. Inter J Appl Biol Pharmacol Technol 2012; 3(2): 146-150

[30] Robbins SL, and Angell M: Basic Pathology.2nd ed. W.B. Saunders Company, Phildelphia, London, 1976

[31] Muller L : Consequences of cadmium toxicity in rat hepatocytes: Mitochondrial dysfunction and lipid peroxidation. Toxicol 1986;40: 285-295

[32] Koyu A, Gokcimen A, Ozguner F, Bayram DS, and Kocak A : Evaluation of the effects of cadmium on rat liver. Mol Cell Biochem 2006;284: 81-85

[33] Liu J, Qu W, and Kadiiska MB: Role of oxidative stress in cadmium toxicity and carcinogenesis. Toxicol Appl
Pharmacol 2009;238: 209-214

[34] Packer, L and Cadenas E: Oxidative Stress and Disease. In: Cadenas, E. and L. Packer (Ed.), Handbook of Antioxidants. 2nd Edn., Marcel Dekker Inc., New York, Basel, USA, 2002, pp. 5-8.

[35] Rikans LE, and Yamano T: Mechanisms of cadmium mediated acute hepatotoxicity. J Biochem Mol Toxicol 2000; 14: $110-117$

[36] Waisberg M, Joseph P, Hale B and Beyersmann D: Molecular and cellular mechanisms of cadmium carcinogenesis: a review. Toxicol 2003;192: 95-117

[37] Ahmad F, and Tabassum N: Experimental models used for the study of antihepatotoxic agents. J Acute Disease 2012: 85-89

[38] Pillai A, and Gupta S: Antioxidant enzyme activity and lipid peroxidation in liver of female rats co-exposed to lead and cadmium: Effects of vitamin E and Mn 2+. Free Radic Res 2005;39: 707-712

[39] Jurczuk, M, Brzoska MM, Moniuszko-Jakoniuk J, Galazyn-Sidorczuk M, and Kulikowska-Karpinska E: Antioxidant enzymes activity and lipid peroxidation in liver and kidney of rats exposed to cadmium and ethanol. Food Chem Toxicol 2004;42: 429-438

[40] Dudley RE, Svoboda DJ, and Klaassen CD: Time course of cadmium-induced ultrastructural changes in rat liver. Toxicol Appl Pharmacol 1984;76: 150-160

[41] Wong LT, Whitehouse LW, Solemonraj G, and Paul CJ: Pathways of acetaminophen conjugation in the mouse. Toxicit Lett 1981;9: 145-151

[42] Savides MC, and Oehne FW: Acetaminophen and its toxicity. J App Toxicol 1983;3: 95-111

[43] Bertin G, and Averback D: Cadmium: Cellular effects, modifications of biomolecules, modulation of DNA repair and genotoxic consequences. Biochim 2006;8: 2549-1559

[44] Kaplan MM: Primary biliary cirrhosis. N Engl J Med 1987;316(9): 521- 528

[45] Adebajo AC, Iwalewa EO, Obuotor EM, Ibikunle GF, Omisore NO, and Adewunmi CO: Pharmacological properties of the extract and some isolated compounds of Clausena lansium stem bark: anti-trichomonal, antidiabetic, anti-inflammatory, hepatoprotective and antioxidant effects. J Ethnopharmacol 2009;122(1): 10-19

[46] Singh VK, Dixit P, and Saxena PN: Cybil induced hepato-biochemical changes in wistar rats. J Environ Biol 2005;26(4): 725-727

[47] Jaramillo-Jurez F, Rodrguez-Vzquez ML, Rincn-Snchez AR, Consolacin Martnez M, Ortiz GG, and Llamas J: Acute renal failure induced by carbon tetrachloride in rats with hepatic cirrhosis. Ann Hepatol. 2008;7(4): 331-338

[48] Bishop LM, Fody, PE and Schoe, HL: Clinical Chemistry Principles, Procedures Correlations 5th ed. Lippincott Williams and Wilkins, Philadelphia, Hong Kong, 2005, pp. $220-253$

[49] Naik P: Biochemistry, 3rd ed, Jaypee Publishers Ltd. Panama, 2010, pp.138-141, 565. 
[50] Liss G, Greenberg RA, and Tamburro CH: Use of serum bile acids in the identification of vinyl chloride hepatotoxicity. Am J Med 1985;78:68-73

[51] Prabu SM, Selvarajan N, Hemalatha S,and Kumar RT: Hepatoprotective effect of Andrographis paniculata on cadmium induced toxicity in male wistar rats. Toxicol Int 2008;15: $21-25$

[52] Prabu MS, Muthumani M and Shagirtha K: Protective effect of piper betle leaf extract against cadmium-induced oxidative stress and hepatic dysfunction in rats. Saudi J Biol Sci 2012;19: 229-239

[53] Yamano T, Shimizu M, and Noda T: Comparative effects of repeated administration of cadmium on kidney, spleen, thymus, and bone marrow in 2-, 4-, and 8-month-old male Wistar rats. Toxicol Sci 1998;46: 393-402

[54] Kaltreider RC, Davis AM, Lariviere JP, and Hamilton JW: Arsenic alters the function of the glucocorticoid receptor as a transcription factor. Environ Health Perspect 2001;109: $245-251$

[55] Osawa T, and Kato Y: Protective role of antioxidative food factors in oxidative stress caused by hyperglycemia. Ann N Y Acad Sci 2005;1043: 440-451

[56] Botsoglou N, Taitzoglou I, Zervos I, Botsoglou E, Tsantarliotou M,and Chatzopoulou PS: Potential of long-term dietary administration of rosemary in improving the antioxidant status of rat tissues following carbon tetrachloride intoxication. Food Chem Toxicol 2010;48: 944-950

[57] Das, S: Hepatoprotective activity of methanol extract of fenugreek seeds on rats. Int J Pharmacol Sci Res 2014;5(4): 1506-1513

[58] Kumar P, and Bhandari U: Protective effect of Trigonella foenum-graecum Linn. on monosodium glutamate-induced dyslipidemia and oxidative stress in rats. Indian J Pharmacol $2013 ; 45: 136-140$

[59] AL-Shaikh MN: Histological and histochemical changes in diabetic male rat liver and intestine and protective effect of cinnamon oil. J Fac Med Baghdad 2010;52(3): 366-371

[60] Kaviarasan S, Ramamurti N, Gunasekaran P, Varalaksmi E, Anuradha CV: Fenugreek (Trigonella foenum-graecum) seed extract prevents etanol-induced toxicity and apoptosis in chang liver cells, Alcohol Alcohol 2006;41 (3): 267-273

[61] Hoefler C, Fleurentier J, Mortier F, Pelt J, and Guillemain J: Comparative choleretic and hepatoprotective properties of young sprouts and total plant extracts of Rosemarinus officinalis in rats. J Ethnopharmacol 1987;19: 133 - 143

[62] Sotelo-Felix J, Martinez-Fong D, and Mureil De la Torre, P: Protective effect of carnosol on CCl4-induced acute liver damage in rats. Europ J Gastroenterol Hepatol 2002;14: 1001-1006

[63] Joyeux M, Roland A, Fleurentin J, Mortier F, and Dorfman P: Tert-Butyl hydroperoxide induced injury isolated rat hepatocytes: a model for studying anti-hepatotoxoxic crude drugs. Plant Med 1990;56:171-174
[64] Del Bano MJ, Castillo J, Garcia OB, Lorente, J, Martin- Gil R, Acevado C, and Alcaraz M: Radio-protective- antimutagenic effects of rosemary phenolics against chromosomal damage induced in human lymphocytes by gamma-rays. J Agric Food Chem 2006;54(6): 2064-2068

[65] Fahim F, Esmat A, Fadel H and Hassan K: Allied studies on the effect of Rosemarinus officinalis L. on experimental hepatotoxicity and mutagenesis. Inter J Food Sci Nutr 1999;50: 413-427

[66] Lamaison J, Petitjean-Freytet C, and Carnat A: Rosemarinic acid, total hydroxycinnamic derivatives and antioxidant activity of Apiaceae, Borranginaceae and Lamiceae medicinals. Annal Pharmacol Fran 1990;48: 103-108

[67] Haraguchi H, Saito T, Okamura N, and Yagi, A: Inhibition of lipid peroxidation and superoxide generation by diterpenoids from Rosemarinus officinalis. Plant Med 1995;61: 333-336

[68] Munne-Bosch S, Schwarz K, and Alegre L: Enhanced Formation of alpha-tecopherol and highly oxidized abietane diterpenes in water-stressed rosemary plants. Plant Physiol 1999;121: 1047-1052

[69] Debersac P, Vernevaut M, Amiot MJ, Suschetet M, and Siess $\mathrm{MH}$ : Effect of a water soluble extract of rosemary and its purified component rosemarinic acid on xenobioticmetabolizing enzymes in rat liver. Food Chem Toxicol 2001;39: 109-117

[70] Shihabudeen MS, Priscilla $\mathrm{H}$, and Thirumurugan K: Cinnamon extract inhibits $\alpha$-glucosidase activity and dampens postprandial glucose excursion in diabetic rats. Nutr Metab 2011;8:1-11

[71] Baek NL, Kim YS, Kyung JS, and Park KH: Isolation of anti-hepatotoxic agents from the roots of Astralagus membranaceous. Korean J Pharmacol 1996;27:111-116

[72] Xiong X, Chen W, Cui J, Yi S, Zhang Z, and Li K: Effects of ursolic acid on liver protection and bile secretion. Zhong Yao Cai 2003;26: 578-581

[73] Tran QI, Adnyana IK, Tezuka Y, Nagaoka T, Tran QK,and Kadota S: Triterpene saponins from Vietnamese ginseng (Panax vietnamensis) and their hepatocyte protective activity. J Nat Prod 2001; 64: 456-61

[74] Vijayan P, Prashanth HC, Dhanraj SA, Badami S, and Suresh B: Hepatoprotective effect of total alkaloid fraction of Solanum pseudocapsicum leaves. Pharmaceut Biol 2003;41: 443-448

[75] Tattini M, Galardi C, Pinelli P, Massai R, Remorini D,and Agati G: Differential accumulation of flavonoids and hydroxyl cinnamates in leaves of Ligustrum vulgare under excess light and drought stress. New Phytol 2004;163: $547-561$

[76] Gould KS, and Lister C: Flavonoid functions in plants. In: Andersen OM, Markham KR (eds.): Flavonoids: chemistry, biochemistry and applications. London: CRC Press, 2006, pp. $397-440$

[77] Heim KE, Tagliaferro AR, and Bobilya DJ: Flavonoid antioxidants: chemistry, metabolism and structure activity relationships. J Nutr Biochem 2002;10:572-584 